\title{
The efficiency of accounting normalization in the matter of intangibles: Asset versus Expense
}

\author{
Houneida Ben Brahim \\ Email: benbrahimhouneida@yahoo.fr \\ Mounira Ben Arab \\ Email: mounira_benarab@yahoo.fr
}

Received: August 14, 2011 Accepted: September 06, $2011 \quad$ DOI: 10.5296/ijafr.v1i1.762

\begin{abstract}
In this paper, we seek to show if the intangible investments may accomplish the recognition's criteria of an intangible asset and we show, thus, if these criteria are capable to preserve the quality of accounting information. We find that the capability of the intangible investments (R\&D), immediately expensed, in the generation of future benefits is more important than the other investments (tangibles and intangibles investments recognized in the balance sheet). This capability is largely influenced by the engagement's degree of the managers. Further, these investments are susceptible to diminish the future earnings volatility and, consequently, their future profits may be measured with reliability and capitalized in the balance sheet as an asset essentially for the firms that have a strong alignment between the manager's and shareholder's interest.
\end{abstract}

Keywords: Normalization, intangible, future benefits, volatility, reliability, managers, compensation. 


\section{Introduction}

Accounting for intangibles constitutes a subject of debate for the accounting profession, especially standard-setting organization, and the accounting practice. Standard setters look for holding the reliability and the verifiability of the provided information to the detriment of its relevance (Lev, 2004). According to the accounting rules (whatever their origin), the accounting information must be reliable and exempts from error and significant bias. The users must have confidence on the accounting data which reflect a faithful view of the firm. The principle of reliability seeks to avoid subjective determinants of the treatment mode and the accounting values of intangibles, such as managerial discretion (FASB, 1974). However, the gap between the market value and the book value reveals a deficiency in the description and reporting of the real wealth of the firms. Thus, the standard makers began to little slacken the conservatism principle in the measure and recording of the intangible assets in order to improve the accounting information. However, this improvement must be insured, simultaneously, by standard makers and by the managers. These last ones may play an important role in the presentation of accounting information on the intangibles and in their impact on the invisible wealth of the firm.

In this paper, we are interested in the American accounting organism, the FASB, because of its important influence on the international accounting regulation. In fact, the international accounting standards of the IASB are largely inspired from the American accounting standards. Further, the IASB and the FASB have adopted, in 2005, a common project of convergence looking for eliminating the major divergences between the two setters such as the divergence in the matter of intangibles.

The criteria of recognition of intangible assets focus generally on the two following international factors:

- $\quad$ the realization of future benefits;

- $\quad$ the certitude degree of the realization of future benefits.

According to the American standard SFAS 142 (Goodwill and Other Intangibles Assets), the intangibles assets may be acquired from the outside or created inside of the firm. The recognition of an asset is based on the evidence of a relation between the immaterial expenditure and the future profitability of the firm. If this relation is approved, the expenditure become an investment and may be capitalized in the balance sheet providing that the costs could be measured with reliable and verifiable way. If these conditions are not filled, the expense will be considered as ordinary expenses. Nevertheless, the outside acquisitions of intangible assets are taken automatically in the balance sheet at their purchase costs. The rules forbid the capitalization of many intangible elements expanded inside of the firm (like R\&D, mark) because the lack of evidence of systematic relation between the engaged expenses and the future profitability. Consequently, there is a discrimination between the intangible investments created inside and the outside acquisitions. For example, the capitalization of R\&D isn't permitted under US accounting rules (SFAS 2, Accounting for Research and 
Development) because that a direct relationship between the $R \& D$ costs and the specific future revenues generally have not been demonstrated. However, the exceptions exist in the matter of R\&D in the software sector (SFAS 2) and in the petroleum and gas sector (SFAS 19).

These exceptions constitute a confirmation form of the usefulness of widening the field of recognition of identifiable intangible assets. Generally, there is a thought concerning the amelioration of the accounting information about the intangible assets such as the elimination of systematic amortization and the recognition of useful life of the asset which may be limited or not limited according to an impairment test. In spite of these efforts for the amelioration of the information, the intangible investment haven't, until yet, a place clearly defined by the conceptual frameworks because the existence of alternative treatments and restrictive rules in favour of the reliability principle and the conservatism. In fact, the characteristics of the intangible elements fit difficulty on the exactness required by the accountancy. Thus, our problematic is to examine empirically the efficiency of the accounting normalization in the determination of the nature of the accounting information about the intangibles (asset or expense). Otherwise, this problematic allows knowing if the accounting normalization in the matter of intangibles favours the offer of faithful and real view of the financial situation and helps the firm to prepare a performing financial reporting.

In spite of the restriction imposed by the rules in order to limit the possibilities of earning management, there are other determinants of the information which exercise an influence on the capacity of intangible investment to generate future profits and on their incertitude because of the existence of agency conflicts in the firm. Far from the accounting standards, the direction may decide to invest or to cut off the expenditures to realize its own interests within the frame of the real earning management. In this way, the incitation of the managers by an interesting remuneration may, on the one hand, limit the dangerous repercussions of the real management and, on the other hand, multiply their efforts to improve the performance of the firm. The administration committees require more and more that the CEO compensation tied strongly to the performance of the firm. Thus, further the fixed and short term portion (salary and bonus), it increases the variable and long term portion of the remuneration (stocks options). For example, The R\&D investment constitutes an uncertain activity and needs specific competences of the managers in order to catch the growth opportunities and to decrease the risks of failure. Consequently, the managers have the possibility to benefit exclusively from the strategic information and probably to own the advantage realized from this activity (Roe, 2002). To avoid this situation, the administration committee stresses on the plans of long term remuneration intended to motivate the managers to react in the interest of the shareholders and to guarantee the profitability of these investments. Therefore, there are factors that influence the accomplishment of the recognition criteria of an asset.

This paper is organized as follows: Section I elaborates on the literature review concerning the matter of reliability and the other determinants of the accounting information about intangibles. Section II presents our hypotheses and methodology. Section III discusses the 
empirical findings and the section IV concludes this paper.

\section{Literature review}

\subsection{The difficult of empirical measure of the reliability}

The reliability is a large concept and less treated by the empirical researches although it is required by the accounting standard and constitutes the major obstacle in front of the capitalization of intangible expenditures (Dahmash and al, 2009). The reliability refers to the uncertainty properties of the estimates that underlie the information (Deng and Lev, 2006). The reliability criterion requires that the estimate of a given phenomenon should result from several independents estimators and offer the same data (for example, the historical cost of fixed assets which is considered as a reliable measure). Many searchers (Lundholm, 1999, Ryan, 1997, Petroni and al, 2001) have proposed a mechanism which borrows the reliability to the estimators. They have suggested to the firms to provide reconciliation of the previous estimations with the actual realizations and to publish, with transparency, the effect of the estimation on the accounting earnings. In this way, the investors can distinguish between the realization and the estimation and consequently they behave suitably. Therefore, the proposed mechanism may be an efficient way for making the financial reporting more relevant and more transparent in an economy based on the information (Aboody and Lev, 1998, Lev and Zarowin, 1999).

Concerning the transparency of the accounting information, Wyatt and Wong (2002) have asserted that when financial reporting is known less transparent concerning intangible assets, it will be characterised by a high dispersion of the predictions and, consequently, it has important absolute errors between realization and prediction. In fact, for getting the transparency, the direction should made many estimators even though the estimation presents some incertitude.

In this way, Barth and al (1999) showed that even if the information is imprecise it may be useful because it has a positive impact on the motivation of the economic agents. Thus, these latter must acquire additional information susceptible to help them in their decision-making-process. So, the fact that the information on the intangible assets is more uncertain rather than other information doesn't mean that this information is untrue and useless to the investors. Indeed, if the capitalized intangible investments in the balance sheet contribute to the realization of future earnings, it has thus a useful informative contribution for the various partners of the company. Entwistle (1999) has indicated that the control of intangible assets and the nature of accounting information allow to the different partners of the firm to orient their prediction of the future performance. However, many studies have criticized the accounting rules because of the asymmetry in the treatment of intangible and tangible investments. The majority of intangible investment is immediately expensed while the tangible investment is taken systematically in the balance sheet. The incertitude of future benefits of intangible investments which makes a lack of reliability of the estimation is considered as the main justification to their immediate expensing (Kothari and al, 2002, 
FASB, 1974). Nevertheless, an insufficient divulgation of the future benefits from the intangible expenditures leads to more information asymmetry. If the management writes off this type of expenditures because it is uncertain to realize future economic benefits or in order to reduce the agency conflicts, the incertitude stays not resolute and the lack of information is not reduced.

Ijiri and Jaedicke (1996) proposed two operational dimensions for the measurement of reliability: the variability of the estimates and the predictive ability. Deng and Lev (2006) have tested if the value of in-process-R\&D (IPRD) capitalized in the balance sheet is reliable and susceptible to assist the investors in the prediction of the future cash flows of the firm. Otherwise, if the IPRD values are associated with a low variability of future cash flows, the IPRD values can be considered reliable, objective and capable to provide a relevant prediction of these cash flows. These searchers have introduced the capital expenditures or physical assets (recognized assets) as a benchmark for IPRD since the reliability is a relative measure. They found that the two independent variables (capital expenditures and IPRD) are positively and significantly associated with cash flows volatility and the coefficient of IPRD substantially lower than that of the capital expenditure. Thus, IPRD is not associated with higher cash flows variability than capital expenditure. However, when the size of the firm and the financial leverage are taken into account in the analysis of this study, the coefficient of the IPRD becomes not significant what means that these latter have the capacity to generate more reliable and certain future profits than the physical assets. So, further investigation should be taken for testing the effects of other control variables on the empirical results and giving explanations. In this sense, the FASB indicates that the accounting normalization must be widely supported by empirical studies to be relevant.

Contrary to the empirical results of Deng and Lev (2006), Kothari and al (2002) provided the evidence that the contribution of $R \& D$ to the future volatility of earnings as a measure of risk is higher than the contribution of physical assets. This conclusion of Kothari and al (2002) confirms the FASB's argument which indicates that the high incertitude of future benefits prevents the managers to provide reliable information about them. However, this difference in the empirical results may be explained by the difference in the measure of profitability. Deng and Lev (2006) have used the cash flows while Kothari and al (2002) have chosen the reported earnings.

\subsection{Other determinants of the accounting information nature on the intangible investment}

According to the accounting standards, the absence of a systematic relationship between intangible expenditures and future profitability and the lack of reliability of the measure bring to write off the expenditures. Then, the decision of expensing or capitalizing returns to these two criteria and essentially to that of generation of the future economic advantages. In fact, this decision which stemming from the management can be influenced by factors others than the strict respect for the standard. The managers may take into consideration several agency conflicts which are susceptible to determine the accounting information nature (asset or expense), the asset value or, even, the volume of expenditures. These agency problems, which 
influence the accounting choices, are more severe in the firms characterized by a high growth opportunity or by a high portion of intangible assets (recognized or not). This situation may lead some managers to adopt an opportunistic behaviour due to greater information asymmetry between them and the shareholders. Many studies have shown a more considerable information asymmetry in the firms with intensity of intangible assets (Barth and al, 2001, Boone and Raman, 2001) which reflects that the lack of recognition of intangible assets in the financial reporting has negative consequences. As a solution of this situation, these firms use more frequently incentive plans of compensation (such as the stocks options) which tied the wealth of managers with the performance of the firm. In this way, Cheffou (2007) found a positive and significant relation between the stocks options granted to the CEO and future performance of the firm. In this case, the managers are more incited to undertake intangible investments susceptible to generate future profits in order to reach a more interesting remuneration. Since it is hard to control the quality of R\&D investments, this mode of compensation helps the increase of the chance that the only successful investments are induced and rewarded (Cheng, 2004). Besides, the managers may be motivated to show correctly the economic advantage of the engaged investments by their capitalization as productive intangible assets capable to realize future profits (if the rules provide accounting alternatives).

Many studies (Baker and al, 1991, Dechow and Sloan, 1991) are interested in the opportunistic reduction in the R\&D spending. Cheng (2004) tied to examine whether the firms seek to mitigate such reduction. He has shown that the compensation committees adjust CEO option compensation to prevent opportunistic reduction in $R \& D$ suggesting that the increase the association between changes in $R \& D$ expenditures and changes in CEO option compensation is effective in mitigating opportunistic reduction in $R \& D$ expenditures. Otherwise, when they anticipate opportunistic reduction in R\&D expenditures, compensation committees could specify the relation between this expenditure and CEO compensation in the bonus contracts and equity incentive plans and enhance a long term performance.

As a real manipulation tool, this reduction or cut off decreases the firm value (Palmrose and al, 2004) due to diminishing of the cash flows in the future periods and the weakness of the growth perspective and the future lost of competitive advantage. In fact, the real earnings management is more opaque than the management by the accounting choices since the real management is more difficult to be detected by the partners of the firm even by the auditors. With the consideration of the danger of real management, Wang and Souza (2006) have shown that the firms with an important accounting flexibility (accounting choices) have weak probability to reduce or cut off the $R \& D$ expenditures.

The study of Oswald and Zarowin (2004) and Ewert and Wagenhoder (2004) have illustrated that the accounting standards may affect the way with which a management chooses to manage their accounting earnings. The empirical results of these studies have shown that the firms which fully expense the R\&D costs are more likely to manage their earnings by reduction of these costs than the firms which may capitalize them. Consequently, the expensing of intangible costs does not limit the earnings management, like the FASB's argument, but it increases the possibility of real earnings management which is more severe 
than the management by the choice of the mode of accounting treatment.

Under the Australian GAAP which offer the choice between expensing and capitalizing, Wyatt (2005) has concluded that the recorded intangible assets are associated with the underlying economics of the firm (like the strength of the technology) that affect the ability to predict and appropriate the investment benefits than other contracting and signalling factors. In contrast, the goodwill and $\mathrm{R} \& \mathrm{D}$ asset provide mixed results. Consequently, the limit of accounting choices in the matter of intangibles tends to reduce rather than improve the information quality provided by the balance sheet.

The choice of the activation or the expensing depends not only on the conditions prescribed by the standard. There are many factors bound to the financial systems, such as the efficient allocation of the capital and the divulgation of the information which are expected to be reflected in the relation between the intangible investments and the future profitability. Then, Karjalainen (2008) studied how the financial system of a country can affect the relation between the investments of R\&D and the future profitability. Besides, he supposed that the uncertainty of the future profits of $R \& D$ can depend on the financial environment of the country.

In a financial environment based on the banks, the strict relation between the bank and the company reduces the request of the public information and offers the protection against the potential competitors. This relation can supply to the bank an idea on the profitability of the firm so that it can finance the feasible and profitable projects. Contrary, in an environment based on the market, the firm is obliged to supply detailed information on its projects to convince the lenders of fund and finance the firm. This information increases the competition between companies and decreases the association between the $R \& D$ and the future profitability of the company. The increase of the competition can make, thus, the future profits more uncertain and strengthens the relation between the R\&D and the uncertainty of the future profitability.

\section{Hypotheses and methodology}

\subsection{Hypotheses}

As it was indicated in the literature review, the reliability principle for accounting of intangibles is preeminent in order to limit the manager's discretion and the possibilities of earnings management. However, is this reliability principle effectively in favour of a faithful accounting view and does it avoid the existence of the other subjective determinants of the accounting values of intangibles?

Indeed, for recognizing of intangible asset, it must assure a reasonable degree of certitude of the realization of future economic advantage which may be measured with reliability. If these conditions are not accomplished, the cost will be expensed. In this way, the intangible assets recorded in the balance sheet should obey to these criteria. Besides, the fact to consider an asset as the sum of the expected future profits was pronounced by several searchers (Collins and al, 1999, Ritter and Wells, 2006). Consequently, we formulate the first hypothesis H1: 
H1: The intangible assets recognized in the balance sheet have a predictive power of the future economic performance.

Otherwise, the intangible costs recorded among the expenses of the current accounting exercise have not future economic advantage. The major characteristic of an expense that distinguishes it from an asset is that it is not expected to generate future benefits. Thus, we deduce the second hypothesis $\mathrm{H} 2$ :

H2: The intangible costs recorded in the expenses of the accounting exercise have not a predictive power of the future economic performance.

For testing the later hypothesis, we choose the $R \& D$ expenditures. The role of $R \& D$ has increased in some companies. Its part is sizable compared to other tangible and intangible values recognized in the balance sheet. A number of prior studies have examined whether alternative R\&D reporting methods affect stocks prices. Nevertheless, previous research did not lead to a consensus about the impact of the $R \& D$ on the income and the economic performance. This last issue remains under research especially in the American context where the $R \& D$ expenditures are classified as expenses and cannot be capitalized without providing a solid argument. Indeed, the reduction in R\&D improves immediately the current earnings. Empirical research documents that R\&D is often manipulated when the managers need to alter net income. Indeed, R\&D expenditure is generally desirable to shareholders but it is not evident for CEO. Thus, this study makes several contributions to the literature and to the accounting rule makers. First, it shows how the CEO compensations affect the relationship between the R\&D expenditures and its specific future revenue. Second, this study shows how the CEO compensations may adjust the uncertainty of this future revenue. The accounting rule makers claim that $R \& D$ is too uncertain to be an asset. But, some challengers (especially Lev and Zarowin, 1999) claim that this level of uncertainty isn't significantly higher than the uncertainty of other corporate investments which are recognized. Furthermore, our study adds to this later claim that the CEO compensations may react on this uncertainty.

In this way, we contribute to the $R \& D$ expensing versus capitalization controversy. This decision must be taken inside of the firm by the consideration of many factors if the standard offers the possibility of choice in the accounting treatment.

\subsection{The sample}

Our sample is constituted by 281 American companies observed over a period going from 1993 to 2005, thus, we have a total of 3372 firm-year observations. This sample was built from the database Compustat. Our sample firms are concentrated in four high tech and science-based industries: 51 firms in pharmaceutics and biotech industry (SIC code 28), 97 firms in software industry (SIC code 73), 70 firms in industrial and commercial machinery and computer equipment industry (SIC code 35), and 63 firms in electronics industry (SIC 
code 36).

In the collect of our sample, we focus in the firms which have information about the intangible assets recognized and the $R \& D$ expenditures over the study period. Thus, the sample selection criteria yield limited firm-year observations but with non-missing data.

We should introduce also the advertising expenditures but using lagged variables for both advertising and R\&D expenditures reduced greatly the sample sizes because the advertising numbers were missing from the data. Eliminating the lagged advertising variables should not result in any significant bias on the estimated parameters given the short-lived effects of the advertising shown in many studies (Sougiannis, 1994).

\subsection{Variables choice}

The variables chosen for the validation of the hypotheses are extracted from the financial annual report that is the balance sheet, the earnings statement, the cash flows statement and the footnotes:

The accounting earnings $(R C)$ : The performance will be measured by the accounting earnings divided on the total assets as the dependant variable. This future performance will be determined on two horizons which are respectively: one year and two years. The earnings adjustment for the current $R \& D$ expenditures is required in order to avoid including them in both sides of the adopted model as components of earnings and as independent variables. We took this measure because it allows reflecting the global effort supplied by the leader to realize this final result;

The intangible assets recorded in the balance sheet (I_INTG): This variable regroups all the elements of the immaterial assets (including the goodwill and divided on the total assets) presented in the balance sheet that are acquired or activated in a reliable way. In this sense, we try to measure the degree of the contribution of these assets in the prediction of the future performance because it is expected, with a reasonable certainty, that they must be capable to generate future economic advantages;

The tangible assets recorded in the balance sheet (I_TANG): According to the accounting regulators, it is considered that the physical or tangible asset (divided on the total assets) can be measured in a more reliable than the intangible asset. So, we should try to check its effect with regard to the effect of the intangible assets on the prediction of the future performance;

The $R D$ expenditures: It is the $\mathrm{R} \& \mathrm{D}$ costs presented in the earnings statement (divided on the total sales). This expenditure is normally considered as being having no capacity to generate future economic advantages or that these last ones cannot be measured in a reliable way;

Manager's remuneration: We are interested in the compensation of the managers to test its effect on the relation between the intangible expenditures and the future performance. In fact, the remuneration can have a considerable effect on the efficiency of the managers in the firm (moderation effect). Only, this efficiency can be different according to the mode of compensation, reason for which we distinguished essentially the following measures of compensation: the short term compensation represented by the cash compensation (salaries 
and annual bonuses noted SAL and BONUS) and the long-term compensation represented by the stocks options (noted OPTION);

\subsection{Regression models}

To test the hypothesis $\mathrm{H} 1$ and H2, we appeal to the following regression model applied to the panel data and allowed the determination of the predictive power of our interested variables:

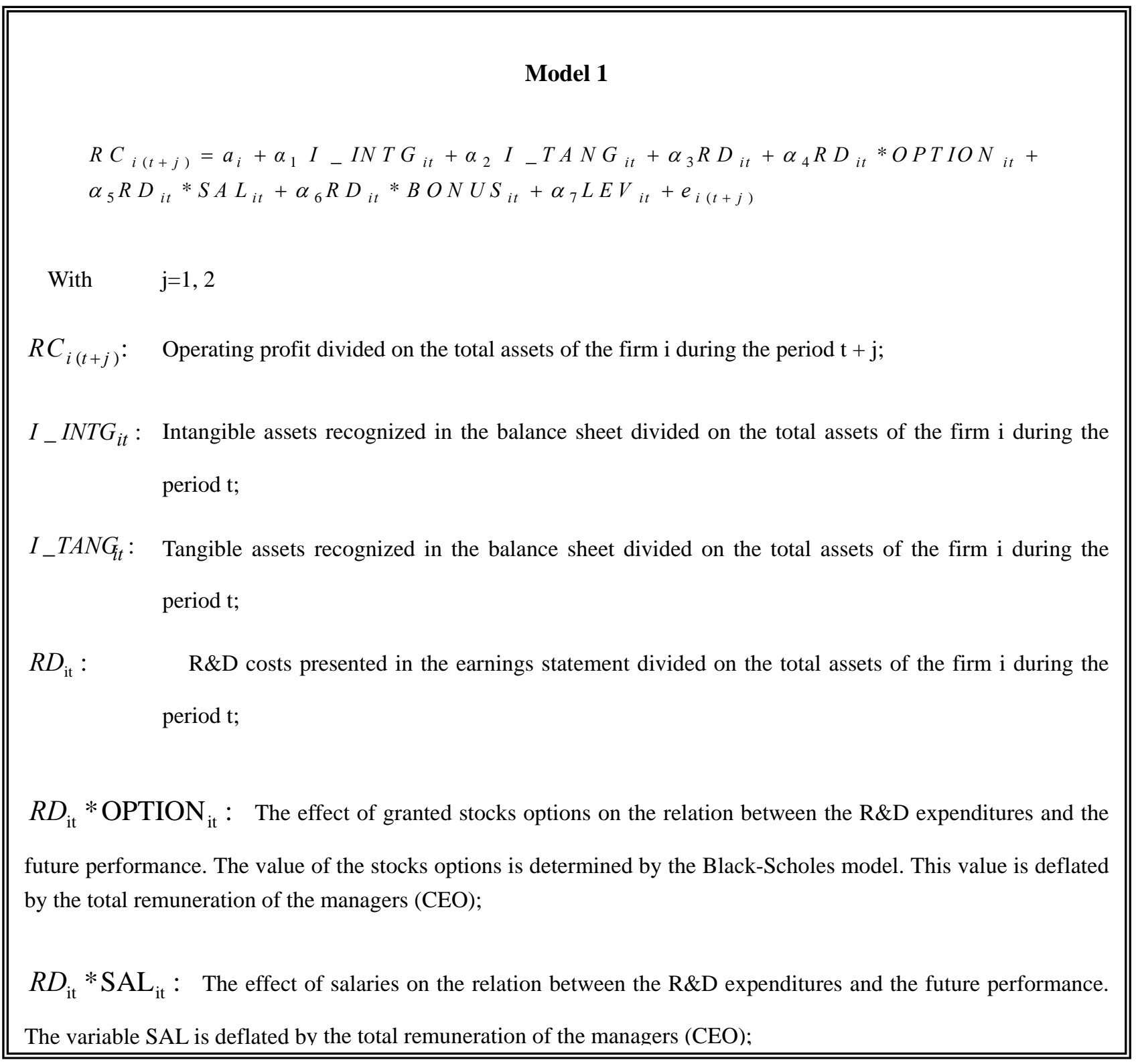


For the recognition of an asset, it isn't enough the generation of the future profits but it is necessary to make certain reliability of the measure of these profits. In fact, the reliability of a measure can be deducted from its relation with the variability of the future profitability as it has been indicated by Cheng and Lev (2006)

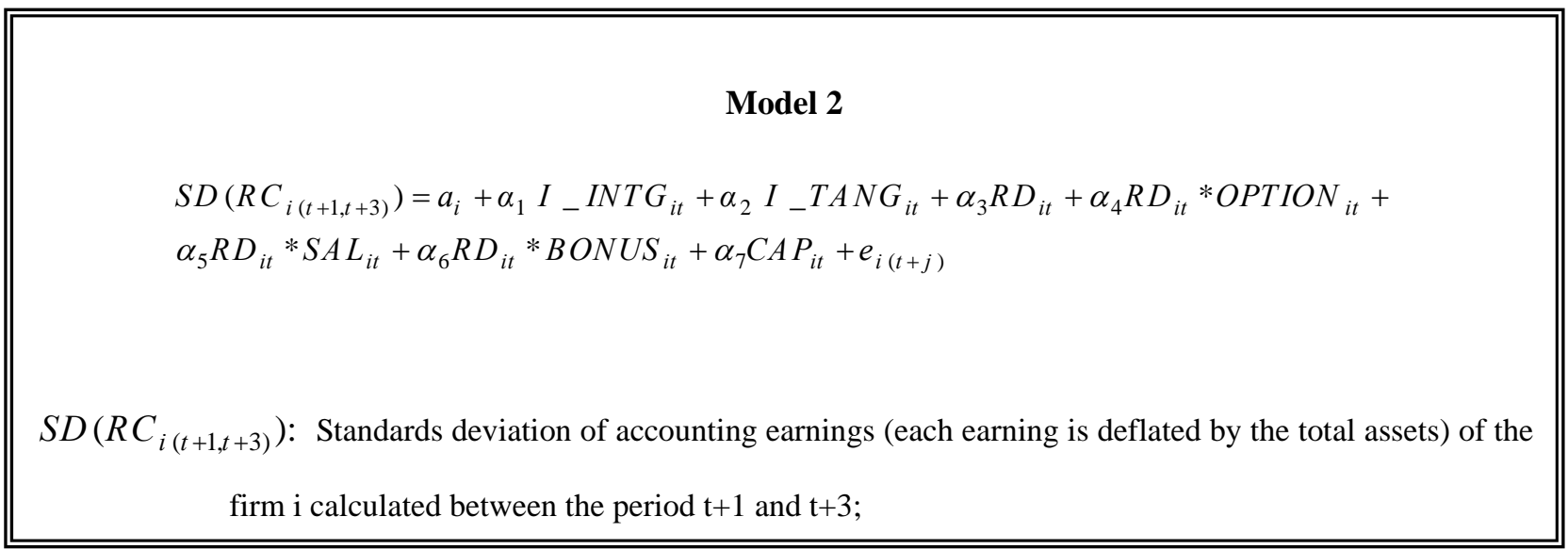

The R\&D investment are considered by accounting standards makers as risky investment having more uncertain future profits rather than those susceptible to be generated by the tangible investment. Consequently, we expect the coefficient on R\&D investment (in our regression 2) to exceed that on tangible investment and intangible investment recognized in the balance sheet. These last ones are activated conveniently to the standards which require a reasonable degree of certitude of the realization of future profits. However, a rigorous theoretical prediction about the relative magnitude of these different coefficients does not exist. We ignore if the financial accounting standard setters have in mind a particular cut-off magnitude of the sensibility of earnings variability to R\&D that would lead them to conclude whether R\&D capitalization should be permitted. Thus, we believe that evidence on the relative impact of $R \& D$ and tangible assets on the future earnings volatility will offer empirical guidance to the current debate on the accounting treatment of $R \& D$ costs, in particular, and intangible costs, in general.

In this part, we introduced the effect of the compensation mode on the contribution of the R\&D investment in the variability of the future earnings. Besides, we have included market value of equity as well-known determinants of earnings variability. According to the literature, earnings variability is expected to decrease in firm size (Lev and Penman, 1990). The large firms may have more diversified projects leading to less volatile earnings than in the case of the small companies. 


\section{Interpretation of empirical results}

\subsection{Descriptive statistics}

The collected data allow us to present the following descriptive statistics presented in the table $n^{\circ} 1$ :

\section{Table 1 : Descriptive statistics}

\begin{tabular}{|l|l|l|l|l|}
\hline \multirow{2}{*}{ Variables } & \multirow{2}{*}{ Means } & \multicolumn{3}{|l|}{ Standard deviation } \\
\cline { 3 - 5 } & & Overall & Between & Within \\
\hline I_TANG & 0,180 & 0,141 & 0,123 & 0,068 \\
I_INTG & 0,108 & 0,181 & 0,110 & 0,144 \\
RC & 0,714 & 4,801 & 2,384 & 4,286 \\
RD & 4,463 & 8,636 & 3,025 & 8,079 \\
SAL & 0,397 & 0,260 & 0,185 & 0,183 \\
BONUS & 0,137 & 0,137 & 0,083 & 0,108 \\
OPTION & 0,417 & 0,306 & 0,201 & 0,230 \\
\hline
\end{tabular}

I_TANG : tangible assets divided on the total assets ; I_INTG : intangible assets divided on the total assets; RC: accounting earnings divided on the total assets; $R D: R \& D$ expenditures divided on total sales; SAL: Value of the annual salaries granted to the managers divided on the total remuneration; BONUS : Value of the annual bonus granted to the managers divided on the total remuneration ; OPTION : Value of stocks options granted to the managers divided on the total remuneration.

According to the descriptive statistics, we notice that the intensity of the R\&D expenditures (R\&D expenditures divided on the total assets) is important within the sample. This importance is increasing during our period as it shows the graph. With the consideration of the weight of these expenses and the opportunities of growth which they offer, it is useful to study their consequence on financial reporting and on future performance.

Since the managers compensation was taken as control variable, we remark that the part of granted stocks options, which have an average of 0,417 , is more considerable than the cash compensation which has an average of 0,397 in the form of salaries and 0,137 in the form of bonus. Besides, several empirical searches showed that the variable part of the remuneration (bonus and stocks options) tends to increase essentially for the managers of the American companies (Milgrom and Roberts, 1997). Indeed, in the firms that having strong growth opportunities, such as the case of our sample, the incentive of the managers by 


\section{I Macrothink}

International Journal of Accounting and Financial Reporting

ISSN 2162-3082

2011, Vol. 1, No. 1

interesting compensation can be effective to capture these opportunities and to converge the interests (Gaver and Gaver, 1993). In this sense, Charreaux (1997) noticed that the adaptation between the manager's interests and those of the shareholders is firstly made by means of the incentive systems that associate the compensation with the realized performance (essentially with the performance drivers).

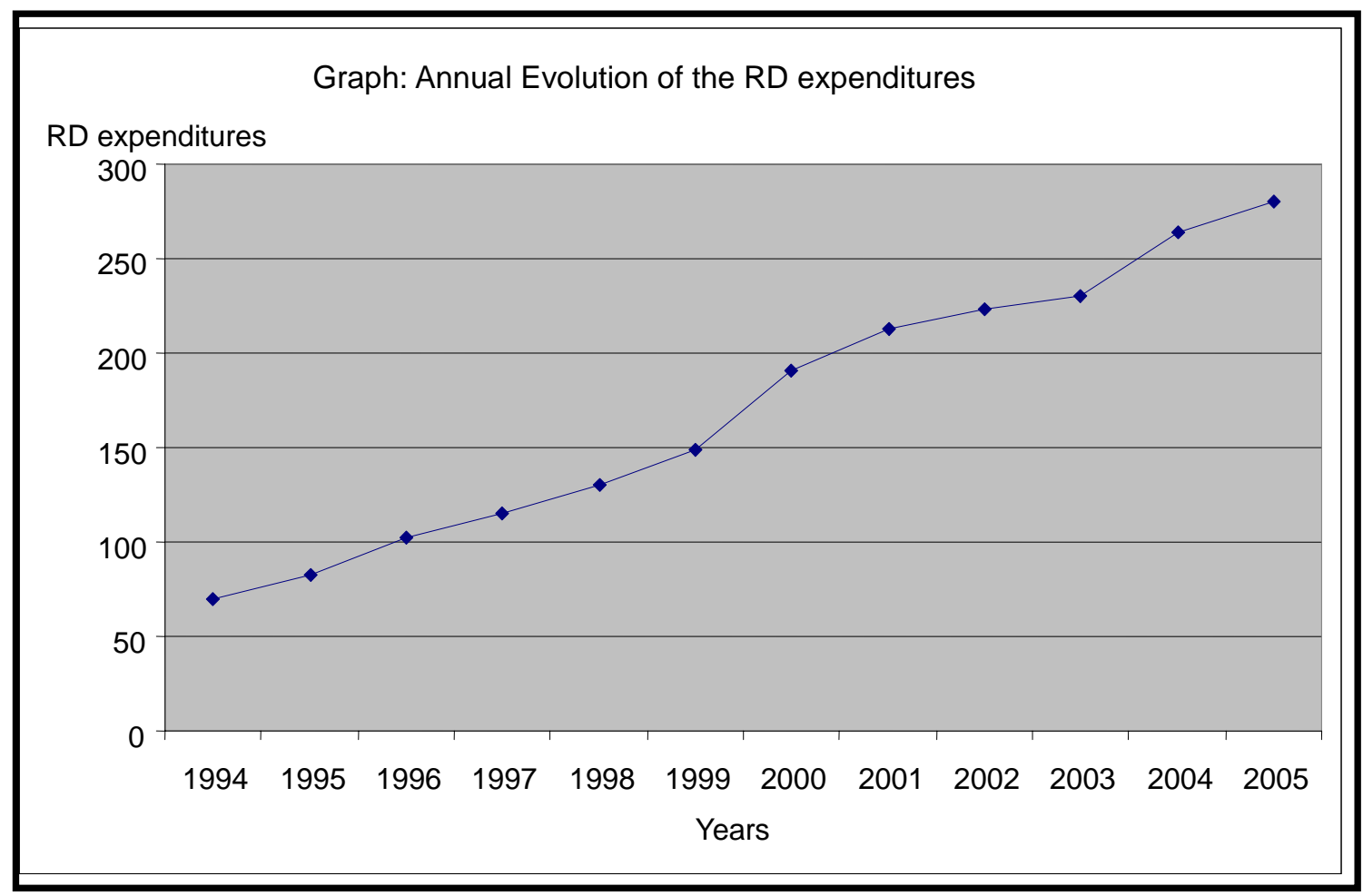

After this exploratory analysis, we will fulfil the multivariate analysis concerning the predictive capacity and the reliability of the measure.

4.2. Multivariate analysis

\subsubsection{The realization of future earnings}

After examining on the STATA the nature of the model (for the two models) which is a model with fixed effect (according to the Hausman's test), we obtain the empirical results presented in the following table: 
Table 2: Empirical results of the regression model 1 of the generation

Of future benefits

$R C_{i(t+j)}=a_{i}+\alpha_{1} I_{-} I N T G_{i t}+\alpha_{2} I_{-} T A N G_{i t}+\alpha_{3} R D_{i t}+\alpha_{4} R D_{i t} * O P T I O N_{i t}+$ $\alpha_{5} R D_{i t} * S A L_{i t}+\alpha_{6} R D_{i t} * B O N U S_{i t}+\alpha_{7} L E V_{i t}+e_{i(t+j)}$

\begin{tabular}{|c|c|c|c|c|c|c|}
\hline \multirow{2}{*}{$\begin{array}{l}\text { Explanatory } \\
\text { variables }\end{array}$} & \multicolumn{3}{|l|}{ Year $\mathrm{t}+1$} & \multicolumn{3}{|l|}{ Year $\mathrm{t}+2$} \\
\hline & Coefficient & $\mathrm{T}$ & Signif & Coefficients & $\mathrm{T}$ & Signif \\
\hline$I_{-} I N T G_{i t}$ & $-0,180$ & $-2,11$ & $0,035 * *$ & 0,138 & 0,94 & $0,347 \mathrm{~ns}$ \\
\hline$I_{-} T A N G_{i t}$ & $-1,890$ & $-2,69$ & $0,007 * * *$ & $-1,958$ & $-2,17$ & $0,03 * *$ \\
\hline$R D_{\text {it }}$ & $-0,289$ & $-2,33$ & $0,020 * *$ & $-0,769$ & $-3,74$ & $\begin{array}{l}0,000 \\
* * *\end{array}$ \\
\hline$R D_{\mathrm{it}} * \mathrm{OPTION}_{\mathrm{it}}$ & 0,292 & 2,32 & $0,020 * *$ & 0,768 & 3,63 & $\begin{array}{l}0,000 \\
* * *\end{array}$ \\
\hline$R D_{\text {it }} * \mathrm{SAL}_{\mathrm{it}}$ & 0,288 & 2,31 & $0,021 * *$ & 0,766 & 3,71 & $\begin{array}{l}0,000 \\
* * *\end{array}$ \\
\hline$R D_{\text {it }} *$ BONUS & 0,316 & 2,45 & $0,014 * *$ & 0,869 & 4,38 & $\begin{array}{l}0,000 \\
* * *\end{array}$ \\
\hline$L E V_{\text {it }}$ & $-0,498$ & $-3,49$ & $0,000 * * *$ & $-1,125$ & $-2,61$ & $\begin{array}{l}0,009 \\
* * *\end{array}$ \\
\hline Intercept & 0,446 & 2,64 & $0,008 * * *$ & 0,685 & 2,25 & $0,024 * *$ \\
\hline Ajusted $\mathrm{R}^{2}$ & 0,241 & & & & 0,44 & \\
\hline $\mathrm{F}$ & $5,95 * * *$ & & & & $13,4 * * *$ & \\
\hline $\mathrm{N}$ & 2524 & & & & 2290 & \\
\hline
\end{tabular}

${ }^{* * *}$ : significant at the level of $1 \% ;^{* *}$ : significant at the level of $5 \%$;

* : significant at the level of $10 \%$; (ns) : not significant at the level of $10 \%$. 
RC: accounting earnings divided on the total assets ; I_INTG : intangible assets divided on the total assets; I_TANG : tangible assets divided on the total assets; RD: R\&D expenditures divided on total sales; OPTION : Value of stocks options granted to the managers divided on the total remuneration; SAL : Value of the annual salaries granted to the managers divided on the total remuneration; BONUS : Value of the annual bonus granted to the managers divided on the total remuneration ; LEV : Total debts divided on the total assets.

We find that for the different horizons $(\mathrm{t}+1$ and $\mathrm{t}+2)$, the model 1 has an important and significant explanatory power. According to the examination of the coefficients on our explanatory variables, we notice that tangible assets have a negative coefficient in the prediction of the future accounting profits on the chosen horizons. We can explain this finding by the capitalism consequence of our days. However, the accounting standards recommend their recognition in the balance sheet since their acquisition or creation. Concerning the predictive capacity of the intangible assets recorded in the balance sheet, we find that they have a negative coefficient $(-0,18)$ which is significant at the level of $5 \%$ only on the horizon $t+1$. But, on the horizon $t+2$, the coefficient becomes non significant on the prediction of the future accounting earnings. Consequently, we reject the hypothesis $\mathrm{H} 1$ which stipulates that these assets have a predictive power of the future performance. Also, the empirical results can show the utility of the new standard which forbids the systematic amortization of the intangible assets in favour of an annual test of depreciation.

Concerning the $R \& D$ investments which are expensed under the requirement of the accounting standards, they have a negative and significant coefficient on the horizon of one year $(-0.289)$ and of two years $(-0,769)$. This suggests that the simple level of the R\&D expenditures does not pull automatically the realization of the future economic advantages (Cazavan-Jeny and Jeanjean, 2005). In fact, the intensity of the R\&D does not allow the discrimination between the profitable and unprofitable projects.

The R\&D investment constitutes a strategic activity for the company (Mayoress and Mohnem, 2005). The decision to invest in this type of risky activity is only made by the managers who hold the whole information about the quality of the R\&D projects and their potential. In fact, the R\&D activities offer to the company the possibilities of innovation and a competitive advantage when they are well executed. So, the manager can influence the capacity of these activities to generate profits. Indeed, the activity of R\&D cannot contribute to the survival, to the growth nor to the profits of the company in the absence of a good strategic management fixed by the managers because it is considered as a strategic function (Hill and al, 2000). Consequently, the manager occupies a central place in the creation of the performance within the company reason for which there are plans of incentive compensation. So, we introduced into our model the effect of the various modes of compensation on the R\&D capacity in the generation of profits. Otherwise, we examine the interaction effect between the R\&D and these various modes on the future earnings. We distinguished, on one hand, the fixed short-term (salary) and the variable (bonus) compensation and, on other hand, the long-term remuneration represented by the stocks options. The latter mode of compensation ties the wealth of the managers to that of the company. 
According to the examination of the empirical findings, we notice that in the presence of the compensation by the stocks options, the R\&D projects have higher capacity in the generation of the future profits on the horizon of one year (0.292) and of two years (0.768). Consequently, following to this mode of incentive compensation, the firm can insure the appropriation of the economic advantages that the R\&D investments can fulfil. Cheng (2004) mentioned that the compensation mode by the stocks options favourite the choice of the good $R \& D$ projects susceptible to guarantee the realization of the future profits. So, the limitations imposed by the accounting standards do not limit the source of managerial discretion over report accounting numbers but incite to a real discretionary manipulation of the investment decisions and create a possibility of dissimulation of the advantages susceptible to be realized by the risky investments characterized by the opaqueness and the ambiguity.

Also, the fixed short term compensation has a positive and significant effect at the level of $10 \%$ on the future profitability of R\&D investments on the horizon of one year $(0.288)$ and two years (0.766). This interaction effect is less considerable than that relative to the stocks options.

Concerning the variable short-term compensation represented by the granted bonus, it generates an interactive effect so positive and significant. On the horizon of one year and of two years, this effect is respectively in the order of 0,316 and 0,869 . Besides, it is more important than the effect concerning the compensation by stocks options and by salary. This can be explained by the fact that the granting of bonus is generally made on the basis of the accounting data such as the accounting earnings. Thus, to increase the accounting earnings, the manager must choose the projects of $R \& D$ that may generate the advantages of which must be superior to the costs committed and counted necessarily in loads.

According to the obtained empirical results, we reject our second hypothesis $\mathrm{H} 2$ indicating that the expenditures recorded in the loads of the current exercise has no predictive power of the future performance. In fact, they may generate future economic advantages over a period at least of two years. Consequently, we conclude that the R\&D must constitute an intangible asset (Sougiannis, 1994, Lev et Zarowin, 1999, Deng and Lev, 2006) since it is able to help the various partners' company to conduct and to correct their predictions of the future performance (Entwistle, 1999). So, as it has been indicated by Lev (2003) in his recommendation, it would be preferable to capitalize and amortize intangible investments over their useful lives in order to more property match costs with future benefits.

We note that we have confirmed our empirical results by setting as variable to predict the operating cash flows instead of the accounting earnings. In fact, the cash flows are considered as being more reliable and objective than the accounting earnings. 
Table 3 : Multivariate regression relative to the generation of the future cash flows $(t+1$ et $\mathbf{t}+2$ )

$$
\begin{aligned}
& C F_{i(t+j)}=a_{i}+\alpha_{1} I_{-} I N T G_{i t}+\alpha_{2} I_{-} T A N G_{i t}+\alpha_{3} R D_{i t}+\alpha_{4} R D_{i t} * \text { OPTION }{ }_{i t}+ \\
& \alpha_{5} R D_{i t} * S A L_{i t}+\alpha_{6} R D_{i t} * \text { BONUS }{ }_{i t}+\alpha_{7} L E V_{i t}+e_{i(t+j)}
\end{aligned}
$$

\begin{tabular}{|c|c|c|c|c|c|c|}
\hline \multirow{2}{*}{$\begin{array}{l}\text { Explanatory } \\
\text { variables }\end{array}$} & \multicolumn{3}{|l|}{ Year $\mathrm{t}+1$} & \multicolumn{3}{|l|}{ Year $\mathrm{t}+2$} \\
\hline & Coefficients & $\mathrm{T}$ & Signif & Coefficients & $\mathrm{T}$ & Signif \\
\hline$I_{-} I N T G_{i t}$ & $-0,131$ & $-2,54$ & $0,011 * *$ & $-0,022$ & $-0,28$ & $0,777 \mathrm{~ns}$ \\
\hline$I_{-} T A N G_{i t}$ & $-1,08$ & $-2,66$ & $\begin{array}{l}0,008 \\
* * *\end{array}$ & $-0,865$ & $-1,7$ & $0,088 *$ \\
\hline$R D_{\text {it }}$ & $-0,117$ & $-2,12$ & $0,034 * *$ & $-0,446$ & $-2,54$ & $0,011 * *$ \\
\hline$R D_{\text {it }} *$ OPTION & 0,115 & 1,99 & $0,047 * *$ & 0,451 & 2,52 & $0,012 * *$ \\
\hline$R D_{\text {it }} * \mathrm{SAL}_{\mathrm{it}}$ & 0,115 & 2,09 & $0,037 * *$ & 0,432 & 2,43 & $0,015 * *$ \\
\hline$R D_{\mathrm{it}} * \mathrm{BONUS}$ & 0,149 & 2,77 & $0,006 * *$ & 0,569 & 3,33 & $\begin{array}{l}0,001 \\
* * *\end{array}$ \\
\hline$L E V_{\text {it }}$ & $-0,353$ & $-3,65$ & $\begin{array}{l}0,000 \\
* * *\end{array}$ & $-0,73$ & $-2,51$ & $0,012 * *$ \\
\hline Intercept & 0,370 & 4,08 & $\begin{array}{l}0,000 \\
* * *\end{array}$ & 0,501 & 2,87 & $\begin{array}{l}0,004 \\
* * *\end{array}$ \\
\hline ajusted $\mathrm{R}^{2}$ & \multicolumn{3}{|l|}{0,50} & \multicolumn{3}{|c|}{0,545} \\
\hline $\mathrm{F}$ & \multicolumn{3}{|l|}{$7,46 * * *$} & \multicolumn{3}{|c|}{$6,39 * * *$} \\
\hline $\mathrm{N}$ & \multicolumn{3}{|l|}{2523} & \multicolumn{3}{|c|}{2289} \\
\hline
\end{tabular}

${ }^{* * *}$ : significant at the level of $1 \% ;^{* *}$ : significant at the level of $5 \%$;

* : significant at the level of $10 \%$; (ns) : not significant at the level of $10 \%$. 


\section{Macrothink}

International Journal of Accounting and Financial Reporting

ISSN 2162-3082

CF : operating cash flows divided on the total assets; I_INTG : intangible assets divided on the total assets; I_TANG : tangible assets divided on the total assets; RD: R\&D expenditures divided on total sales; OPTION : Value of stocks options granted to the managers divided on the total remuneration; SAL : Value of the annual salaries granted to the managers divided on the total remuneration; BONUS : Value of the annual bonus granted to the managers divided on the total remuneration ; LEV : Total debts divided on the total assets.

According to the table $\mathrm{n}^{\circ}$, the model based on the cash flows as dependent variable presents a more important global explanatory power than the accounting earnings as well on the horizon $\mathrm{t}+1$ as on the horizon $\mathrm{t}+2$. This last model confirms strongly the empirical findings brought out of the previous model and on the both horizons. This can strengthen our interpretations.

Besides, it is possible to predict the operating cash flows on the horizon $t+3$ by using the same explanatory variables, as it shown in the table $n^{\circ} 4$. Also, the predictive power of our explanatory variables did not change. While, for the prediction of the accounting earnings, the model loses its global significativity on the horizon $t+3$. Consequently, we can say that the cash flow allows reflecting better as well the relation between the $R \& D$ expenditure and the future performance as the role of the managers in the determination of this relation. 
Table 4 : Multivariate regression relative to the generation of the future cash flows $(t+3)$

$C F_{i(t+3)}=a_{i}+\alpha_{1} I_{-} I N T G_{i t}+\alpha_{2} I_{-}$TANG $_{i t}+\alpha_{3} R D_{i t}+\alpha_{4} R D_{i t} *$ OPTION ${ }_{i t}+$

$\alpha_{5} R D_{i t} * S A L_{i t}+\alpha_{6} R D_{i t} * B O N U S_{i t}+\alpha_{7} L E V_{i t}+e_{i(t+j)}$

\begin{tabular}{|c|c|c|c|}
\hline \multirow[t]{2}{*}{ Explanatory variables } & \multicolumn{3}{|l|}{ Year $\mathrm{t}+3$} \\
\hline & Coefficients & $\mathrm{T}$ & Significativity \\
\hline$I_{-} I N T G_{i t}$ & 0,087 & 0,31 & $0,753 \mathrm{~ns}$ \\
\hline$I_{-} T A N G_{i t}$ & $-2,417$ & $-1,41$ & $0,160 \mathrm{~ns}$ \\
\hline$R D_{\text {it }}$ & $-0,608$ & $-1,76$ & $0,079 *$ \\
\hline$R D_{\text {it }} *$ OPTION & 0,604 & 1,68 & $0,093 *$ \\
\hline$R D_{\text {it }} * \mathrm{SAL}_{\mathrm{it}}$ & 0,601 & 1,76 & $0,078 *$ \\
\hline$R D_{\text {it }} *$ BONUS & 0,739 & 2,01 & $0,044 * *$ \\
\hline$L E V_{\text {it }}$ & $-1,945$ & $-1,52$ & $0,130 \mathrm{~ns}$ \\
\hline Intercept & 1,306 & 1,67 & $0,096 *$ \\
\hline ajusted $\mathrm{R}^{2}$ & 0,33 & & \\
\hline $\mathrm{F}$ & $9,41 * * *$ & & \\
\hline $\mathrm{N}$ & 2055 & & \\
\hline
\end{tabular}

${ }^{* * *}$ : significant at the level of $1 \%{ }^{* *}$ : significant at the level of $5 \%$;

* : significant at the level of $10 \%$; (ns) : not significant at the level of $10 \%$.

CF : operating cash flows divided on the total assets; I_INTG : intangible assets divided on the total assets; I_TANG : tangible assets divided on the total assets; RD: R\&D expenditures divided on total sales; OPTION : Value of stocks options granted to the managers divided on the total remuneration; SAL : Value of the annual salaries granted to the 
managers divided on the total remuneration; BONUS : Value of the annual bonus granted to the managers divided on the total remuneration ; LEV : Total debts divided on the total assets.

\subsubsection{The measure reliability of intangible investment}

The empirical findings are presented in the following table $\mathrm{n}^{\circ} 5$ for the examination of the measure reliability of intangible investment:

Table 5 : Empirical results of the regression model of the volatility the future accounting earnings

\section{Panel A :}

$S D\left(R C_{i(t+1, t+3)}\right)=a_{i}+\alpha_{1} I_{-} I N T G_{i t}+\alpha_{2} I_{-} T A N G_{i t}+\alpha_{3} R D_{i t}+\alpha_{4} R D_{i t} *$ OPTION $_{i t}+$ $\alpha_{5} R D_{i t} * S A L_{i t}+\alpha_{6} R D_{i t} * B O N U S_{i t}+\alpha_{7} C A P_{i t}+e_{i(t+j)}$

\begin{tabular}{|l|l|l|l|}
\hline Explanatory variables & Coefficients & $\mathrm{T}$ & Significativity \\
\hline$I_{-} I N T G_{i t}$ & $-0,307$ & $-1,38$ & $0,169 \mathrm{~ns}$ \\
$I_{-} T A N G_{i t}$ & 4,258 & 1,32 & $0,187 \mathrm{~ns}$ \\
$R D_{\text {it }}$ & 0,249 & 1,97 & $0,047 * *$ \\
$R D_{\text {it }} *$ OPTION & $-0,254$ & $-1,97$ & $0,05 * *$ \\
$R D_{\text {it }} *$ SAL it & $-0,242$ & $-1,91$ & $0,05 * *$ \\
$R D_{\text {it }}^{*}$ BONUS & $-0,307$ & $-2,36$ & $0,01 * * *$ \\
$C A P_{\text {it }}$ & $-0,098$ & $-2,33$ & $0,02 * * *$ \\
Constante & 0,095 & 0,18 & $0,855 \mathrm{~ns}$ \\
\hline Ajusted ${ }^{2}$ & 0,156 & 2285 & \\
$\mathrm{~F}_{\mathrm{N}}$ & $3,79 * * *$ & \\
\hline
\end{tabular}

${ }^{* * *}$ : significant at the level of $1 \% ;^{* *}$ : significant at the level of $5 \%$;

* : significant at the level of $10 \%$; (ns) : not significant at the level of $10 \%$. 
$S D\left(R C_{i(t+1, t+3)}\right)$ : Standard deviation of future accounting earnings (Every observation is divided on the total assets) of the firm i calculated between the period $t+1$ and $t+3$; I_INTG : intangible assets recognized by the balance sheet divided on the total assets; I_TANG : Tangible assets divided on the total assets ; RD : Expenditure R\&D divided on the sales; OPTION : Value of stocks options granted to the managers divided on the total remuneration; SAL : Value of the annual salaries granted to the managers divided on the total remuneration; BONUS: Value of the annual bonus granted to the managers divided on the total remuneration; CAP : Log decimal of the market capitalization.

Table 5 : Empirical results of the regression model of the volatility of the future cash flows (continued)

\section{Panel B :}

$$
\begin{aligned}
& S D\left(C F_{i(t+1, t+3)}\right)=a_{i}+\alpha_{1} I_{-} I N T G_{i t}+\alpha_{2} I_{-} T A N G_{i t}+\alpha_{3} R D_{i t}+\alpha_{4} R D_{i t} * O P T I O N_{i t}+ \\
& \alpha_{5} R D_{i t} * S A L_{i t}+\alpha_{6} R D_{i t} * \text { BONUS }_{i t}+\alpha_{7} L E V_{i t}+\alpha_{8} C A P_{i t}+e_{i(t+j)}
\end{aligned}
$$

\begin{tabular}{|l|l|l|l|}
\hline Explanatory variables & Coefficients & $\mathrm{T}$ & Significativity \\
\hline$I_{-} I N T G_{i t}$ & $-0,067$ & $-1,02$ & $0,307 \mathrm{~ns}$ \\
$I_{-} T A N G_{i t}$ & 1,870 & 1,56 & $0,118 \mathrm{~ns}$ \\
$R D_{\text {it }}$ & 0,332 & 2,74 & $0,006 * * *$ \\
$R D_{\text {it }} *$ OPTION & $-0,340$ & $-2,77$ & $0,006 * * *$ \\
$R D_{\text {it }} *$ SAL & $-0,322$ & $-2,63$ & $0,009 * * *$ \\
$R D_{\text {it }} *$ BONUS & $-0,392$ & $-3,30$ & $0,001 * * *$ \\
$C A P_{\text {it }}$ & $-0,093$ & $-3,39$ & $0,001 * * *$ \\
Constante & 0,403 & 1,60 & $0,110 \mathrm{~ns}$ \\
\hline Ajusted ${ }^{2}$ & $5,03 * * *$ & & \\
$\mathrm{~F}^{\mathrm{N}}$ & 0,217 & & \\
\hline
\end{tabular}


: significant at the level of $1 \%$; $^{* *}$ : significant at the level of $5 \%$;

* : significant at the level of $10 \%$; (ns) : not significant at the level of $10 \%$.

$S D\left(C F_{i(t+1, t+3)}\right)$ : Standard deviation of future operating cash flows (Every observation is divided on the total assets) of the firm i calculated between the period $t+1$ and $t+3$; I_INTG : intangible assets recognized by the balance sheet divided on the total assets; I_TANG : Tangible assets divided on the total assets ; RD : Expenditure R\&D divided on the sales; OPTION : Value of stocks options granted to the managers divided on the total remuneration; SAL : Value of the annual salaries granted to the managers divided on the total remuneration; BONUS: Value of the annual bonus granted to the managers divided on the total remuneration; CAP : Log decimal of the market capitalization.

According to the argument pronounced by the normalizers, it is expected that earnings variability stemming from $R \& D$ investment far exceeds that attributable to capital expenditure. This volatility indicates lack of the reliability of the future profits which the $R \& D$ investments can realize. The activation of these latter is generally forbidden by the standards even in the presence of the future economic advantages.

Following to the empirical findings (table $n^{\circ}$ ), we find that the coefficient on the recognized intangible assets is negative but not significant. Thus, more the company recognizes its intangible assets more the volatility of its future profits decreases. In contrast, the tangible investments has a positive effect but not significant. This empirical result strengthens the place of the intangible assets within the modern companies. Besides, their recognition allows an improvement of the correspondence between the costs and the profits and consequently the decrease of the variability of the future earnings and the future cash flows.

Concerning the R\&D investment, it contributes significantly to the volatility of the future accounting earnings $(0.249)$ and the future cash flows $(0.332)$. This finding is similar to that of Kargalainen (2008). In this study, he found that the R\&D product more volatility than the tangible investment. Nevertheless, Karjalainen (2008) found a positive and significant coefficient concerning the tangible investments on the basis of a sample constituted by the companies of various countries while our study gave a positive and not significant coefficient.

By introducing the different modes of compensation, we find that the $R \& D$ investment decreases the volatility of the future accounting earnings and cash flows because the coefficient of the interaction between these investments and the different modes of compensation is significantly negative. This coefficient is very important with regard to the other coefficients on the model. Therefore, the uncertainty relative to the future profits of the $R \& D$ is not totally ties to the nature of the investment but it can be moderated by governance factors. Besides, this uncertainty did not prevent the standard makers from allowing the capitalization of the of R\&D costs in the petroleum and gas industry (SFAS 19) and in the software sector (SFAS 2) under the pressure of the various actors requiring an information about the quality of these expenses. Consequently, we cannot say that the R\&D investments 
generate future profits more uncertain than the tangible investments. This does not confirm the argument pronounced by the accounting standard setters concerning the lack of the reliability of the future profits inherent to the intangible investments (Deng and Lev, 2006) to be capitalized in the balance sheet. In this sense, Lev (2003) recommended, on one hand, capitalization with amortization and impairment tests and, on the other hand, expensing with conditional reversion. When an intangible asset is acquired or created and its future economic benefits are within a reasonable certainty, the recognition criteria of an asset are satisfied, its cost should be capitalized and subsequently amortized over its useful life. If the expected value of the asset falls below its book value, the value has to be written down immediately to its expected value. When an intangible resource is acquired or created, but its future economic benefit is beyond reasonable certainty so that the ordinary criteria for asset recognition are not valid, its costs should be expensed in the period in which they were incurred. The costs should be expensed even though the expected value of the intangible resource is positive (conservatism). If in a subsequent period the future economic benefits start to flow and thus become within reasonable certainty, the previously expensed cost should be capitalized. The reversion should be seen as a change of estimate recognized by accounting standards able to produce an informative signal to investors and other financial statement users: earnings are affected negatively in the year the costs are expensed, signalling that the investment probably is lost; earnings are affected positively in the year of capitalization signalling that an intangible asset with future economic benefits has been created. Thus, the income variation caused by conditional reversion is a signal of earnings potential and susceptible to increase the value relevance of financial statement (Krohn and Knivsfla, 2000). Consequently, the accounting normalization concerning the intangible can increase the information asymmetry and stress the conflicts of interest especially between the shareholders and the managers because it does not facilitate the transparency of the information.

\section{Conclusion}

The problem of accounting intangible treatment stays a source of debate of the accounting standard regulators, the practitioners, the researchers and the financial analysts. The efforts invested in the improvement of the accounting information in the intangible remain insufficient in front of the economic reality of these investments and their relative importance in the prediction of the future financial performance. Indeed, rules determining the appropriate accounting qualitative (asset or expense) are generally restrictive and do not allow a better understanding of the economic nature of this investment type. In this way, we made our research by asking the question of the efficiency of the accounting normalization in the matter of intangible. Two main conditions generally imposed by the standard to consider an investment as asset are the generation of the future profits and the measure reliability of these profits.

According to the empirical findings, we found that the intangible assets recognized in the balance sheet do not allow the generation of the future profits on a horizon of two years. Concerning the R\&D investments of which the standard forbids generally their activation, the simple level of the expenditure does not reflect their capacity to realize future profits on an 
horizon of two years or more. This capacity of profitability is insured when the managers are implied in their company by an interesting compensation which depends directly on the wealth of the company. The incentive compensation allows the company to suit the future economic advantages fulfilled by the $R \& D$ investments and to guarantee a good strategic management of these investments.

Make sure the realization of the future profits for the capitalization of the intangible expenditures is insufficient; it is also necessary to make sure their reliability. In fact, the trade-off between the relevance and the reliability is a major concern in the accounting normalization setting. The trade-off suggests balancing the demand for value-relevant information by the investors and with the demand for reliable information by the different contracting parties. In this research, we focused the interest on the dimension of the reliability measured by the volatility of the future accounting earnings and the future cash flows.

According to the empirical findings, we found that the intangibles assets recognized by the balance sheet decrease the variability of the future profits and the future cash flows what insures their reliability. On the other hand, the tangible assets increase this volatility. Concerning the $R \& D$ investments, we noticed that their contribution in the volatility of the future profits is positive and significant rather than the tangible assets recognized by the balance sheet. Only, the managers can react on this uncertainty when there is an alignment of their interests with those of the shareholders for an interesting compensation. So, we found that the interaction between the R\&D and every compensation mode allows decreasing the volatility of the future accounting earnings and the future cash flows. However, under the pretext to protect the reliability of the information, the normalizers confer to the managers the possibility of benefiting from advantages of the intangible investment by limiting their activation. Consequently, our empirical results approve that the capitalization allows the improvement of the quality of accounting reporting by producing a convenient information with the accounting qualitative fixed by the standards (asset or expense). In this sense, we suggest to grant more margins to the discretion of the managers who are the main holders of the internal and strategic information. This means recommending more flexibility in the accounting standards in a changeable and complex environment. Only, this recommendation is effective only when the manager's discretion is directed to the global interest of the company. A good orientation of the managers can be determined by effective mechanisms of governance. In our study, we showed the efficiency of an interesting compensation, as a governance mechanism, on the efficiency of the R\&D investment. Consequently, for the elaboration or the revision of the accounting standards, regulators have to consider several factors acting on the quality of the supplied information. So, several ways of future search can be handled such as the effect of the other mechanisms of governance or control (example, the external audit) on the manager's efficiency in the commitment of the intangible expenditures and in the suitable accomplishment of the recognition criteria of an economic asset. 


\section{References}

Aboody, D., and Lev, B., 1998, R\&D and insiders gains, Working Paper, University of California, July ;

Baker, W., Fairfield, P., and Haggard, J., 1991, The effect on concern about reported income on discretionary spending decisions: The case of research and development, The Accounting Review, Vol 66, p. 818-829;

Barth, M., Kasznik, R., and McNichols, M., 2001, Analyst coverage and intangible assets, Journal of accounting Research, Vol 39, NÂ 1, p. 1-34;

Boone, J., and Raman, K.K., 2001, Off balance sheet RD and market liquidity, Journal of Accounting and Public Policy, Vol 20, NÂ², p. 97-128;

Cheffou, A., 2007, Les stock-options en faveur des dirigeants : dÃ@terminants dâ ${ }^{\mathrm{TM}}$ octroi et impact sur la performance des entreprises, le cas franÃßais, Working Paper, Universit $\tilde{A} \subset$ Paris Dauphine ;

Cheng, S., 2004, R\&D expenditures and CEO compensation, The Accounting Review, Volume 79, NÂ 2, p. 304-328;

Collins, D.W., Pincus, M., and Xie, H., 1999, Equity valuation and negative earnings: The role of book value of equity, The Accounting Review, Vol 74, NÂ 1, p. 29-61;

Dechow, P., and Sloan, R., 1991, Executive incentives and horizon problem, Journal of Accounting and Economics, Vol 14, p. 41-89;

http://dx.doi.org/10.1016/0167-7187(91)90058-S

Deng, Z., and Lev, B., 2006, In-process RD: To capitalize or expense? Journal of Engineering And Technology Management, Vol 23, NÂ 1, p. 18-32 ;

Entwisthe, G.M., 1999, Exploring the RD disclosure environment, Accounting Horizons, Vol 13, NÂ० 4, p. 323-341;

Ewert, R., and Wagenhofer, A., 2005, Economic effects of tightening accounting standards to restrict earnings management, The Accounting Review, Vol 80, p. 1101-1124;

http://dx.doi.org/10.2308/accr.2005.80.4.1101

Financial Accounting Standards Board, 1974, Statement of Financial Accounting Standard NÂ 2 : Accounting for Research and Development Costs, Stamford, Connecticut;

Financial Accounting Standards Board, 2001b, Statement NÂ 142, Goodwill and Other Intangible Assets, Norwalk, Connecticut; 
Hill, S., Martin, R., and Harris, M., 2000, Decentralization, integration and post-bureautic organization: The case of R\&D, Journal of Management Studies, Vol 37, NÂ 4, p. 563-586 ;

Ijiri, Y., and Jaedicke, R., 1996, Reliability and objectivity of accounting measurements, The Accounting Review, July, p. 474-483;

Karjalainen, P., 2008, R\&D investments : The effects of different financial environments on firm profitability, Journal of Multinational Financial Management, Vol 18, p. 79-93;

http://dx.doi.org/10.1016/j.mulfin.2007.02.006

Kothari, S.P., Laguerre, T.E., and Leone, A.J., 2002, Capitalization versus expensing : Evidence on the uncertainty of future earnings from capital expenditures versus R\&D outlays, Review of Accounting Studies, Vol 7, NÂ 4, p. 355-382;

Lev, B., and Penman, S.H., 1990, Voluntary forecast disclosures, nondisclosure, and stock prices, Journal of Accounting Research, Vol 28, NÂ 1, p. 49-76;

Lev, B., and Zarowin, P., 1999, The boundaries of financial reporting and how to extend them, Journal of Accounting Research, Vol 37, NÂ 3, p. 353-385;

Lev, B., 2003, Remarks on the measurement, valuation and reporting of intangibles assets, Economic Policy Review, September, p. 17-22;

Lev, B., 2004, Sharpening the intangibles edge, Harvard Business Review, June, p.109-116; PMid:15202292

Lundholm, R., 1999, Reporting on the past: A new approach to improving Accounting today, Accounting Horizons, December, p. 315-323;

Oswald, D., et Zarowin, P., 2004, The capitalization, amortization and value relevance of RD, Working Paper, NYU ;

Palmrose, Z., Richardson, et SCholz, 2004, Determinants of market reactions to restatement announcements, Journal of Accounting and Economics, Vol 37, 2004, p.59-89;

http://dx.doi.org/10.1016/j.jacceco.2003.06.003

Petroni, K., Ryan, S., and Wohlen, J., 2001, Discretionary and non-discretionary revisions of loss reserves by property causality insurers : differential implications for future profitability, Risk and market value, Accounting Studies, Vol 5, NÂ 2, p. 95-125;

Ritter, A., and Wells, P., 2006, Identifiable intangible asset disclosures, stocks prices and future earnings, Accounting and Finance, Vol 46, NÂ 5 , p. 843-863; 
Roe, J.M., 2002, les rentes et leurs cons $\tilde{A} @$ quences en mati $\tilde{A}$ re de gouvernance des entreprises, Finance ContrÃ'le StratÃ@gie, Vol 5, NÂํ 1, p. 167-215;

Ryan, S., 1997, A survey of research relating accounting numbers to systematic equity risk, with implication for risk disclosure policy and future research, Accounting Horizons, Vol 11, NÂ 2, p. 82-95;

Sougiannis, T., 1994, The accounting based valuation of corporate R\&D, The Accounting Review, Vol 69, NÂ¹, p. 44-68;

Wang, S., and Souza, J., 2006, Earnings management : The effect of accounting flexibility on RD investment choices, Working Paper, Cornell University ;

Wyatt, A., 2005, Accounting recognition of intangibles assets : Theory and evidence on economic determinants, The Accounting Review, Vol 80, NÂ 3, p. 967-1003;

Wyatt, A., and Abernethy, M., 2003, Framework for measurement and reporting on intangible assets, Intellectual Property Research Institute of Australia, Working Paper $n \hat{A}^{\circ} 12 / 03$; 